\title{
Financial Deepening And Financial Performance Of Deposit Money Banks In Nigeria
}

\author{
Mulkat Ajibola Yusuff \\ Department of General Studies, \\ The Federal Polytechnic, Ilaro \\ Fatimah Olabisi Olaniran-Akinyele \\ Department of Banking \& Finance, \\ The Federal Polytechnic, Ilaro
}

\begin{abstract}
This study examines the effect of financial deepening on financial performance of Nigerian Deposit Money Banks using time-series data spanning 1990Q1-2017Q4. The financial performance is expressed by return on assets (ROA) and return on equity (ROE) with total bank liability, private sector credit and market capitalization as measure of financial deepening. The technique of analysis deployed is autoregressive distributed lag (ARDL) to co integration. The findings show that the effect of total bank liability is positive and significant. Market capitalization and private sector credit on the other hand exert negative and significant effect. The study concludes that financial deepening affect financial performance of Deposit Money Banks in Nigeria. It then recommends effective loan recovery strategy to mitigate the negative influence of private sector credit due to non-performing loans.
\end{abstract}

Keywords: Financial deepening, Financial performance, Deposit Money Bank, Autoregressive Distributed Lag, Non-performing loans

\section{INTRODUCTION}

The growth of any nation is fully linked to that nation's financial sector of which commercial banks are essential component. Commercial banks (known as Deposit Money Banks in Nigeria) are financial intermediator that connect the sectors of the economy with idle funds to the sectors that are in dear need of funds for investment thereby expediting capital formation and trade. Put in different way, commercial banks perform intermediating role by accepting deposits and used such to make loans of different maturities either fixed or at variable rates and earn profit through interest rates spread by charging for services provided (Ron, 2012 as cited in Olawunmi, Lateef and Oladeji, 2017).

The reforms in Nigerian financial system became expedient when it was obvious that a wide gap exists between the financial sector and the real sector of the economy. One of the reforms that specifically involved the banking sub-sector is the policy of consolidation. Prior to the implementation of the policy, the banking sub-sector were characterized by large number of small banks, low capital base, declining asset quality and weak corporate governance. The prominent feature of consolidation is the recapitalization exercise in which the maximum paid -up capital of commercial banks was raised to twenty-five billion naira. The essence is to financially deepen the banking sector to enhance its competitiveness and capability for effective discharging of the intermediation role in development and finance of investment opportunities in all sectors of the economy (Olawumi, Lateef \& Oladeji, 2017). 
In order to carry out financial intermediation function continually banks need to generate enough income to offset the operating cost incurred in the process. In other words, good financial standing is required to ensure sustainable intermediation function. Good financial performance is not only a pre-condition for effective intermediation process but also rewards the shareholders for their investments as well as encourages additional investments (Ongore \& Kusa, 2013). Bank financial performance therefore has serious effect on investment, firm growth, industrial expansion and economic growth (Sheefeni, 2015).

Bank financial performance is mostly determined by its ability to generate profit. A bank is profitable if it can accrue financial gains from its operational activities of mobilizing idle funds from depositors to the investors. In order words there is interconnectivity between financial deepening, intermediation function and profitability of banks. Hence, the goal of this study is to examine the influence of financial deepening on profitability of deposit money banks in Nigeria.

\section{LITERATURE REVIEW}

There exists a plethora of studies on factors influencing banks' financial performance in literature. These studies have been skewed toward investigation of the effect of bank-specific (internal) factors or macroeconomic (external)factors or the two combined. The empirical investigation into the connection between financial deepening and banks' financial performance have not received ample attention. A host of studies (Athanasogou et.al., 2008; Li, 2009; Zhang and Dong, 2011; Ongore and Kusa, 2013; Nuriyeva, 2014; Lee et.al., 2015; Shinla and Sharma, 2016; Ozgur and Gorus, 2016; Tan, 2016; Hasanov, Bayramil and Al-Musehel, 2018) that have investigated the effect of both bank-specific and macroeconomic factors on bank financial performance found that bank-specific factors even though vary along the varieties of datasets employed play very significant role in explaining banks' financial performance. The findings on effects of macroeconomic factors however remained inconclusive as macroeconomic environment studied differs.

Nuhiu, Hoti \& Bektashi (2017) discovered that profitability of commercial banks in Kosovo is driven mainly by internal factors like capital adequacy, asset quality and management efficiency. The macroeconomic factors proxy by GDP and inflation on the other hand have positive insignificant effect.

Akinkunmi (2017) found that of all bank-specific measures (capital adequacy, liquidity risks, credit risks and efficiency ratio) employed, only efficiency ratio is a crucial factor that influence profitability of commercial banks in Nigeria. The macroeconomic variables - real GDP growth rate, inflation rate and market concentration however have no significant influence

In the study of Hasanov, Bayramil \& Al-Musehel (2018) bank-specific measures such as net profit, total assets, total equity, total loans, total deposits and short-term funding including macroeconomic variables like total and non-oil GDP, inflation expectation, exchange rate devaluation and changes in oil prices were found to be significant in determining profitability of commercial banks in Azerbaijan.

The recent study of Aspal, Dhawan and Nazneen (2019) equally found that all bank-specific variables used-asset quality, management efficiency, earning quality and liquidity with the exception of capital adequacy ratio have significant relationship with financial performance of some sample banks in India. In the case of macroeconomic variables only GDP growth rate significantly affect the banks' performance, the effect of inflation is statistically insignificant. 
Other studies that specifically investigated the link between macroeconomic factors and bank financial performance could also not come up with conclusive findings. (Seferli, 2010; Babazadeh and Farrokhnejad, 2012; Otuori, 2013; Kiganda, 2014; Martinho, Oliviera and Oliviera, 2017; Ghurtskaia, 2018). The study of Kanwal \& Nadeem (2013) revealed that the macroeconomic factors selected: real GDP growth rate, real interest rate and inflation rate have negligible impact on profitability of commercial banks in Pakistan. Sheefeni (2015) utilized the same set of macroeconomic variables and in contrast found that the macroeconomic environment does not play a role in influencing profitability of commercial banks in Namibia.

The empirical research on the link between financial deepening and financial performance of bank is scanty. The few existing studies employed measures such as credit to private sector, money supply, deposit liability, credit accessibility and financial innovation. The outcome of Andele (2013) study showed that financial deepening contributed to growth of profit in Kenyans' commercial banks. Olawumi, Lateef and Oladeji (2017) and Nancy (2017) in their respective studies gave support to the findings of Andele (2013). Although slightly different, Kisaka, Ndii, Muriki and Muio (2015) reported a weak positive relationship between mobile bank deepening and commercial banks' financial performance.

In light of the above review, this study intends to add to the pool of empirical studies by examining the linkage between financial deepening and profitability of commercial banks in Nigeria. Olawumi, Lateef and Oladeji (2017) that pioneered the study in Nigeria only investigated some selected commercial banks. This study however differs in that the entire conglomerate of commercial banks is studied and different measures of profitability are used.

\section{Theoretical Models}

\section{METHODOLOGY AND DATA ISSUES}

The focus of this study is on the impact of financial deepening on the profitability of deposit money bank. The traditional measures of profitability that are widely used are Return on Assets (ROA) and Return on Equity (ROE). While Return on Assets indicates the extent of profit a company's asset is able to generate, Return on Equity on the other hand shows how much profit is generated by shareholders' investments. This study adopts the two measures of profitability. Regarding the financial deepening, only bank based measures comprising of private sector credit, market capitalization and total bank deposit all as ratio of GDP were employed for the study. The models for the study are expressed as follows

$$
\begin{array}{ll}
\text { Model: } 1 & \text { ROA }=f(\text { CPSG, MCG, BDLG }) \\
\text { Model: } 2 & \text { ROE }=f(\text { CPSG, MCG, BDLG })
\end{array}
$$

The econometric models to be estimated is obtained by linearizing equations $1 \& 2$ and restated below:

Where:

$$
\begin{aligned}
& \mathrm{ROA}=\alpha+\beta \mathrm{CPSG}+\delta \mathrm{MCG}+\lambda \mathrm{BDLG}+\varepsilon_{\mathrm{t}} \\
& \mathrm{ROE}=\alpha+\beta \mathrm{CPSG}+\delta \mathrm{MCG}+\lambda \mathrm{BDLG}+\varepsilon_{\mathrm{t}}
\end{aligned}
$$

ROA = Return on Assets

ROE = Return on Equity

$\mathrm{CPSG}=$ Private Sector Credit $/$ GDP

$\mathrm{MCG}=$ Market Capitalization / GDP

BDLG = Bank Deposit Liability / GDP

$\alpha=$ Constant Parameter 
$\beta, \delta, \lambda=$ Coefficients of Estimation

$\varepsilon_{\mathrm{t}}=$ Error Term

\section{Nature of Data and Data Sources}

The data used for this study are secondary in nature. They are quarterly data for the period 1997Q1 to 2017Q4. Data on return on assets and return on equity were obtained from the World Bank Global Financial Development Database. All the financial deepening measures were sourced from the Central Bank of Nigeria Statistical Bulletin.

\section{Estimating Procedure}

The Autoregressive Distributed Lag (ARDL) bounds test approach proposed by Pesaran, Smith and Shin (2001) was adopted in this study to estimate the long run and short run dynamic relationship among the variables of interest. This approach was chosen based on the premix that it is suitable for small sample size study and also allows for estimation of system that contains both I(0) and I(1) variables. In ARDL approach the long run equation to be estimated is given in equations 5 and 6 .

$$
\begin{aligned}
& \triangle R O A_{t}=\delta_{0}+\delta_{i} R O A_{t-i}+\delta_{j} C P S G_{t-j}+\delta_{k} M C G_{t-k}+\delta_{l} B D L G_{t-l}+\sum_{i=1}^{q} \varphi_{i} \Delta R O A_{t-i}+ \\
& \sum_{j=0}^{m} \varphi_{j} \Delta C P S G_{t-j}+\sum_{k=0}^{n} \varphi_{k} \Delta M C G_{t-k}+\sum_{l=0}^{p} \varphi_{l} \Delta B D L G_{t-l}+\varepsilon_{t} \\
& \mathrm{i}=1, \ldots . . ., \mathrm{q} ; \mathrm{j}=0, \ldots \ldots ., \mathrm{m} ; \mathrm{k}=0, \ldots \ldots . ., \mathrm{n} ; \mathrm{l}=0, \ldots \ldots . . \mathrm{p} \\
& \Delta R O E_{t}=\gamma_{0}+\gamma_{r} R O E_{t-r}+\gamma_{u} C P S G_{t-u}+\gamma_{v} M C G_{t-v}+\gamma_{w} B D L G_{t-w}+\sum_{r=1}^{b} \emptyset_{r} \Delta R O E_{t-r}+ \\
& \sum_{u=0}^{d} \emptyset_{u} \Delta C P S G_{t-u}+\sum_{v=0}^{f} \emptyset_{v} \Delta M C G_{t-v}+\sum_{w=0}^{g} \emptyset_{w} \Delta B D L G_{t-w}+\varepsilon_{t} \\
& \mathrm{r}=1, \ldots \ldots \ldots . \mathrm{b} ; \mathrm{u}=0, \ldots \ldots . . \mathrm{d} ; \mathrm{v}=0, \ldots \ldots . ., \mathrm{f} ; \mathrm{w}=0, \ldots \ldots \ldots . . \mathrm{g}
\end{aligned}
$$

Before estimating equations 5 and 6, ARDL bound test was conducted to verify the existence of cointegration between the dependents and explanatory variables. In bound test, the null hypothesis $\left(\mathrm{H}_{0}\right)$ is tested against the alternative hypothesis $\left(\mathrm{H}_{\mathrm{A}}\right)$ using F- statistic from the Wald test. That is,

$\mathrm{H}_{0}: \delta_{i}=\delta_{j}=\delta_{k}=\delta_{l}=0 ; \mathrm{H}_{\mathrm{A}}: \delta_{i} \neq \delta_{j} \neq \delta_{k} \neq \delta_{l} \neq 0$

$\mathrm{H}_{0}: \gamma_{r}=\gamma_{u}=\gamma_{v}=\gamma_{w}=0 ; \mathrm{H}_{\mathrm{A}}: \gamma_{r} \neq \gamma_{u} \neq \gamma_{v} \neq \gamma_{w} \neq 0$

When the computed F-statistic is higher than the upper critical value, the $\mathrm{H}_{0}$ of no long run relationship is rejected. Otherwise, it is accepted when the computed F-statistic falls below the lower critical value. Once the existence of cointegration is established, the short run dynamic parameters are obtained by estimating error correction model associated with the long run estimates. The error correction model is specified as:

$$
\begin{aligned}
& \triangle R O A_{t}=\omega_{0}+\sum_{i=1}^{v_{1}} \omega_{i \triangle R O A_{t-i}}+\sum_{j=0}^{V_{2}} \omega_{j \Delta C P S G_{t-j}}+\sum_{k=0}^{v_{3}} \omega_{k \Delta M C G_{t-k}}+\sum_{l=0}^{v_{4}} \omega_{l \Delta B D L G_{t-l}}+ \\
& E C T_{t-1}
\end{aligned}
$$
... (8)

$$
\mathrm{r}=1, \ldots \ldots \mathrm{Q}_{1} ; \mathrm{u}=0, \ldots \ldots ., \mathrm{Q}_{2} ; \mathrm{v}=0, \ldots \ldots . ., \mathrm{Q}_{3} ; \mathrm{w}=0, \ldots \ldots \ldots, \mathrm{Q}_{4}
$$

\section{Descriptive Statistics}

\section{PRESENTATION OF FINDINGS AND DISCUSSION}

The properties of the data employed in the study were first verified in order to provide an unobjectionable outcome. The result of the descriptive statistics is presented in the table 1 below 


\begin{tabular}{|l|c|c|c|c|c|}
\hline \multicolumn{7}{|c}{ Table 1: Descriptive Statistics } \\
\hline Mean & ROE & ROA & LNMCG & CPSG & BDLG \\
\hline Maximum & 15.19571 & 2.133140 & 2.610069 & 14.13810 & 27.62106 \\
\hline Minimum & 34.86906 & 3.287878 & 3.687629 & 23.10000 & 40.65000 \\
\hline Std. Dev. & 0.135313 & 0.220000 & 1.731656 & 7.700000 & 14.44250 \\
\hline Skewness & 7.472285 & 0.666305 & 0.517216 & 6.177727 & 6.379770 \\
\hline Kurtosis & 0.546219 & -0.408932 & -0.290193 & 0.162203 & -0.018454 \\
\hline & 3.456530 & 3.017434 & 2.021935 & 1.191949 & 2.576349 \\
\hline Jarque-Bera & 4.906445 & 2.258565 & 4.356427 & 11.81001 & 0.602808 \\
\hline Probability & 0.086016 & 0.323265 & 0.112735 & 0.002726 & 0.739779 \\
\hline & & & & & \\
\hline Sum & 1276.440 & 172.7843 & 211.4156 & 1187.600 & 2209.685 \\
\hline Sum Sq. Dev. & 4634.308 & 35.51702 & 21.40100 & 3167.638 & 3215.415 \\
\hline & & & & & \\
\hline Observations & 84 & 84 & 84 & 84 & 84 \\
\hline
\end{tabular}

Source: Computed by the Authors (2019)

The results in table 1 show that all the variables have positive mean. The respective standard deviation of each variable falls below their various means indicating that there are no outlier or weakness around the variables. Furthermore, all the variables with the exception of private sector credit/GDP (CPSG) are normally distributed given non significance of probability of their various Jarque-Bera estimates at the level of significance of 5 percent.

\section{Unit Root Tests Result}

Getting the order of integration is a necessary requisite that gives a guide onto the type of method to adopt in determining the long run relationship among the variables in a study. To this end, Augmented Dickey Fuller (ADF) and Phillip Perron tests statistic were deployed to check the order of integration in this study and the results are shown in table 2

Table 2: Unit Root Results

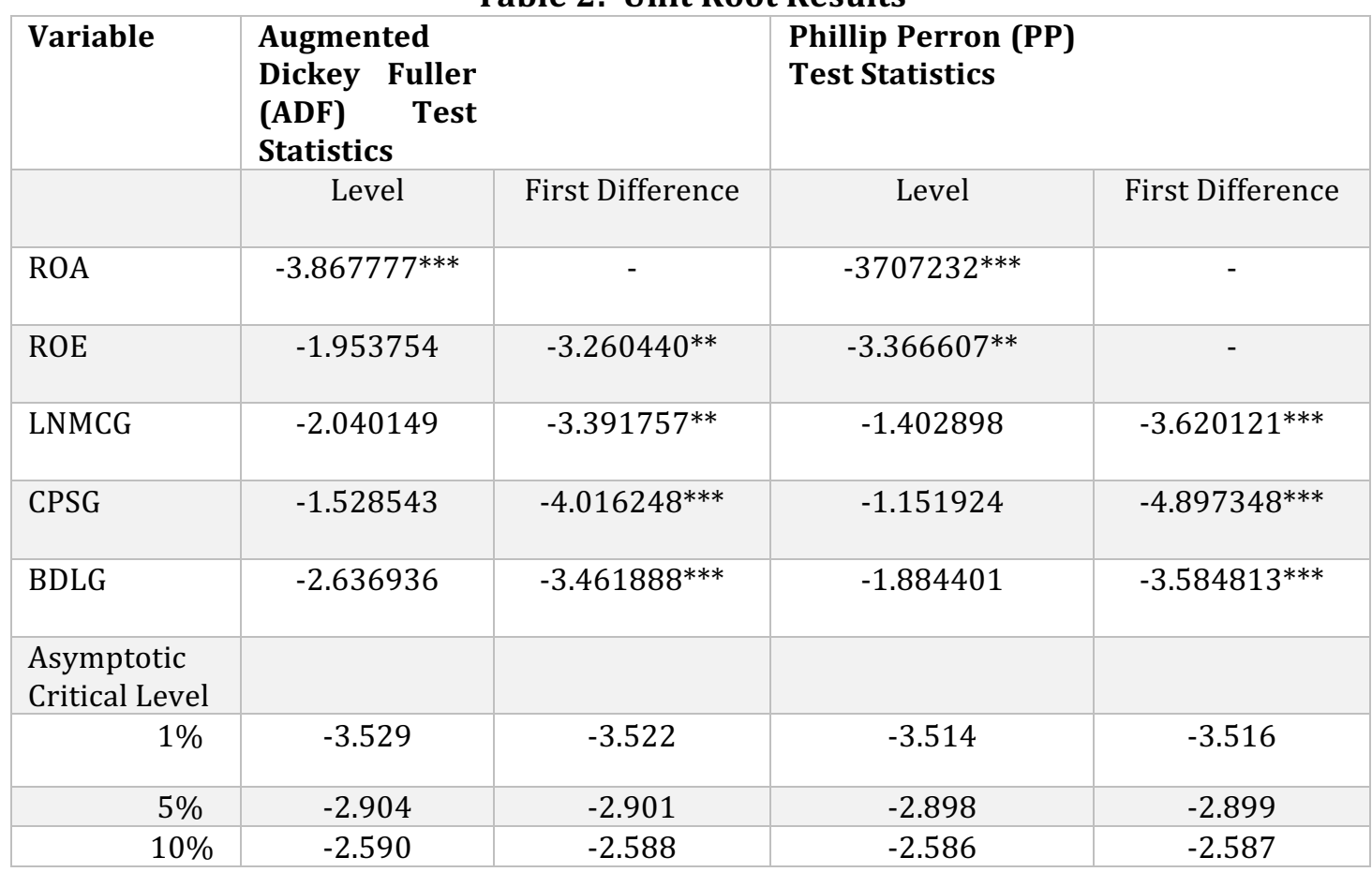

Source: Computed by the Authors (2019)

Note: $1 \%, 5 \%, 10 \%$ significance level is denoted by ${ }^{* * *},{ }^{* *}, *$ respectively. 
As shown in table 2, ADF test indicates that return on assets (ROA) is stationary at level and integrated of order I (0). The other variables; return on equity (ROE), market capitalization (LNMCG), bank deposit liability (BDLG) and private sector credit (CPSG) are all stationary at first difference and therefore integrated of order I (1). These results were confirmed by PhillipPerron test excluding return on equity (ROE) that is stationary at the level by the test.

\section{Cointegration Test Results}

Having established that the series contains both I (0) and I (1), bounds test approach to cointegration was used to find out whether or not long run co-movement exists among the variables. It is important that the estimating variables cointegrate before any meaningful conclusion could be made about the relationship among the series. The outcome of this investigation is displayed in table $3 \mathrm{a} \& \mathrm{~b}$.

Table 3a: ARDL Bound Test Result for ROA
Table 3b: ARDL Bound Test Result for ROE

\begin{tabular}{l|cc|cc}
\hline \multicolumn{1}{c}{ LOS } & I (0) & I (1) & I (0) & I (1) \\
\hline $10 \%$ & 2.37 & 3.20 & 2.37 & 3.20 \\
$5 \%$ & 2.79 & 3.67 & 2.79 & 3.67 \\
$2.5 \%$ & 3.15 & 4.08 & 3.15 & 4.08 \\
$1 \%$ & 3.65 & 4.66 & 3.65 & 4.66 \\
F-stat & & 6.298438 & & \multicolumn{2}{c}{5.033530} \\
K & \multicolumn{2}{c}{3} & & 3
\end{tabular}

Source: $\quad$ Computed by the Authors (2019)

As can be observed in table 3, the null hypothesis of no long run relationship is rejected. The estimated F-statistic from the Wald test for the two models: ROA (6.298438) and ROE (5.033530) are greater than the 5\% upper bound (3.67) in each case. This implies that there is cointegration among the variables in the two models.

\section{Long Run and Short Run Estimation}

Since the existence of cointegration is confirmed, the long run and the short run dynamics associated with the long run are then analyzed for the two models. The outcomes are presented in tables 4 and 5. 
Table 4: ARDL Long and Short- run Results for Model 1

Dependent Variable: ROA ARDL $(4,3,3,4)$ based on AIC

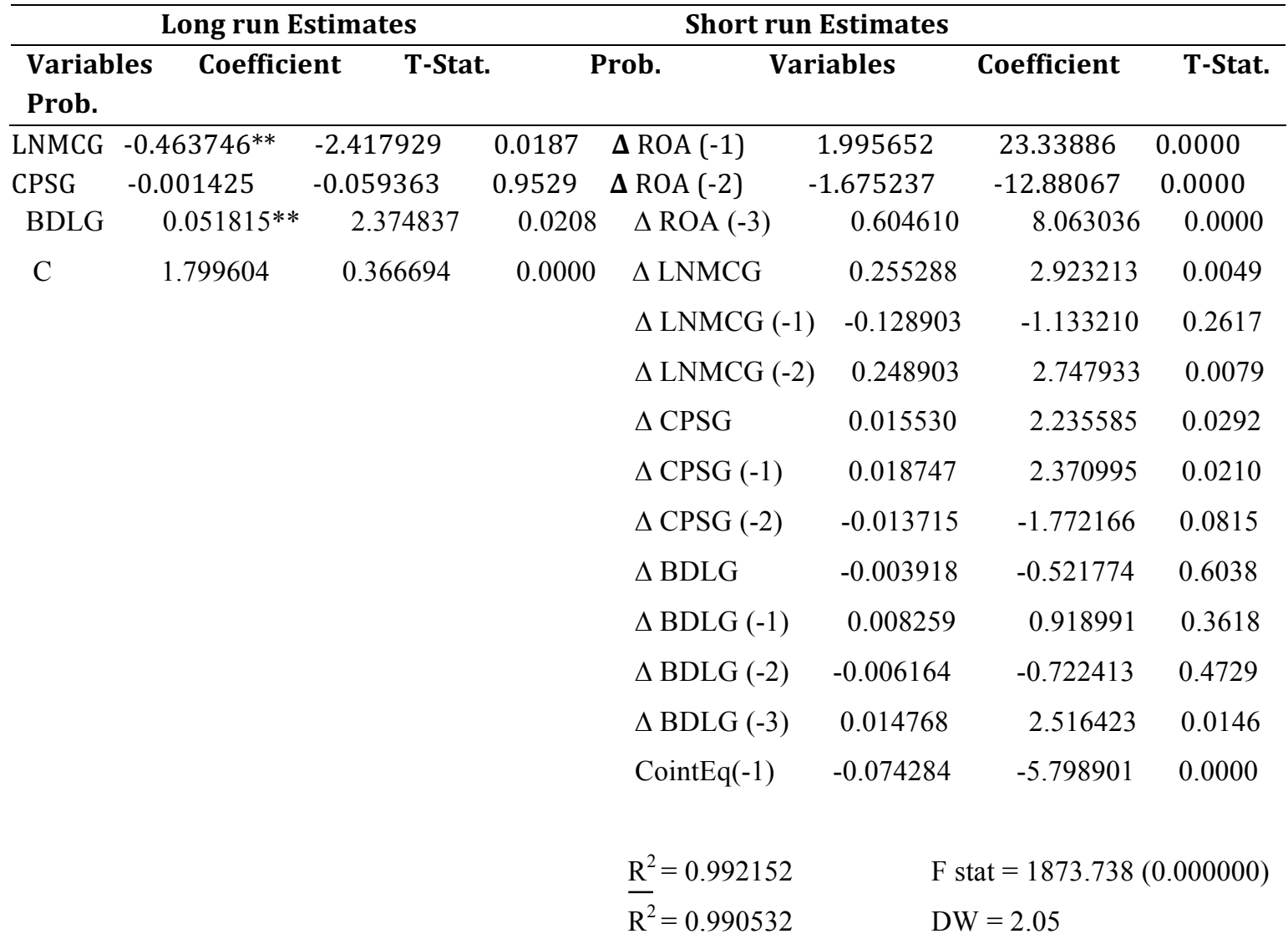

Source: Computed by the Authors (2019)

** indicates $5 \%$ level of significance

Table 5: ARDL Long and Short- run Results for Model 2

Dependent Variable: ROE ARDL $(3,0,2,1)$ based on AIC

\begin{tabular}{|c|c|c|c|c|c|c|c|}
\hline & \multicolumn{2}{|c|}{ Long run Estimates } & \multicolumn{4}{|c|}{ Short run Estimates } & \multirow[b]{2}{*}{ Prob. } \\
\hline Variables & Coefficient & T-Stat. & Prob. & Variables & Coefficient & T-Stat. & \\
\hline LNMCG & -4.718823 & -1.492993 & 0.1401 & $\Delta \operatorname{ROE}(-1)$ & 0.464705 & 4.933386 & 0.0000 \\
\hline CPSG & $-0.704472 * *$ & -2.447328 & 0.0170 & $\Delta \operatorname{ROE}(-2)$ & 0.226812 & 2.391672 & 0.0195 \\
\hline BDLG & $0.684809 * *$ & 2.202007 & 0.0311 & $\triangle \mathrm{CPSG}$ & -2.480315 & -5.746537 & 0.0000 \\
\hline \multirow[t]{5}{*}{$\mathrm{C}$} & 19.20131 & 2.998089 & 0.0038 & $\Delta \mathrm{CPSG}(-1)$ & 0.829468 & 2.057128 & 0.0435 \\
\hline & & & & $\Delta \mathrm{BDLG}$ & 0.789820 & 2.381044 & 0.0201 \\
\hline & & & & CointEq(-1) & -0.283234 & -5.162180 & 0.0000 \\
\hline & & & & \multicolumn{2}{|c|}{$\mathrm{R}^{2}=0.561455$} & \multicolumn{2}{|c|}{ F stat $=63.01013(0.000000)$} \\
\hline & & & & \multicolumn{2}{|c|}{$\mathrm{R}^{2}=0.531001$} & \multicolumn{2}{|c|}{$\mathrm{DW}=2.09$} \\
\hline
\end{tabular}

\section{Source:}

Computed by the Authors (2019)

$* *$ indicates $5 \%$ level of significance

The results of ARDL analysis as demonstrated in table 4 involving return on assets (ROA) shows that the relationship between market capitalization as ratio of GDP and ROA is indirect and significant in the long run but direct and significant in the short run. Specifically, 1\% increase in market capitalization as ratio of GDP (MCG) will induce $0.46 \%$ reduction in ROA in 
the long run while 1\% increase in MCG will induce $0.26 \%$ increase in ROA in the short run. This implies that the ratio of market capitalization to GDP have influence on profitability measured by return on assets.

The result of the long run analysis of private sector credit as ratio of GDP and ROA indicates an indirect and insignificant relationship. In particular, a unit increase in CPSG will stimulate 0.001 unit reduction in ROA. In short run however, the relationship is direct and significant in the early part but as the years progress the relationship skewed towards indirect and insignificant which probably explained the long run situation. A unit increase in CPSG will induce 0.016unit increase in ROA while a unit increase in CPSG lag 2 will lead to 0.014unit decrease in ROA.

The kind of relationship exhibited by bank deposit as ratio of GDP to ROA is in contrast to that of CPSG. The relationship started as indirect and insignificant in the short run and become direct and significant in the long run. In the short run a unit increase in BDLG will induce 0.004 units decrease in ROA in the first instance, while a unit increase in BDLG lag 3 will stimulate 0.015 unit increase in ROA as the year progresses. In the long run, a unit increase in BDLG will stimulate 0.051unit increase in ROA. This long run result confirmed the study of Olawumi, Lateef and Oladeji (2017) which found that bank deposit liabilities have positive effect on profitability of deposit money bank.

The statistical properties of the regression result as displayed in table 4 indicates adjusted $\mathrm{R}^{2}$ of 0.990532 , implying that $99 \%$ of variation in ROA is collectively explained by the measures of financial deepening used in the study. The F-statistic value (1873.378 [0.0000]) is highly significant indicating that the measures of financial deepening joined together have significant influence on ROA. The Durbin-Watson statistic of approximately 2 confirmed the absence of autocorrelation. The coefficient of error correction ECT (-0.074) is correctly signed and significant indicating that that about $7 \%$ of any deviation that might occur in the short run are corrected in the long run.

Regarding the long run and short run results involving return on equity (ROE) in table 5, market capitalization/GDP (MCG) exerts negative and insignificant influence on ROE in the long run. Precisely, 1\% increase in MCG will initiate $4.72 \%$ decrease in ROE. However, in the short run it does not have any influence. Private sector credit/GDP (CPSG) exerts negative and significant influence on ROE both in the long run and short run. A unit increase in CPSG will stimulate 0.70unit decrease in ROE in the long run and 2.5units decrease in ROE in the short run. This result is in contrast to the findings of Olawumi, Lateef and Oladeji (2017) that CPSG influence profitability positively. In the case of bank deposit/GDP (BDLG), its influence is positive and significant on ROE in the long run as well as in the short run. A unit increase in BDLG will induce 0.68unit increase in ROE in the long run and 0.79 unit increase in the short run.

The adjusted $\mathrm{R}^{2}$ is 0.53 indicating that $53 \%$ of variation in ROE in jointly explained by the measures of financial deepening. The F-statistic of $63.01013(0.00000)$ is significant implying that all the measures of financial deepening used in the study collectively have significant impact on ROE. Durbin-Watson (2.09) shows that the result is free from autocorrelation. The coefficient of error correction ECT $(-0.28)$ is negative and significant showing that $28 \%$ of deviations in short run will be corrected along long run equilibrium. 


\section{Residual Diagnostics and Stability Tests Results}

Several residual diagnostics and stability tests were further conducted to lay credence to the robustness of the ARDL models estimated. The results of these tests are shown in table 6 and figures 1 to 4 .

Table 6: Results of Residual Diagnostics Tests

\begin{tabular}{|c|c|c|c|c|}
\hline Tests & $\begin{array}{c}\text { Normality(Jaque- } \\
\text { Bera)Test }\end{array}$ & $\begin{array}{c}\text { Ramsey Reset } \\
\text { Test }\end{array}$ & $\begin{array}{c}\text { Serial Corr. LM } \\
\text { Test }\end{array}$ & $\begin{array}{c}\text { Hetero. (BPG) } \\
\text { Test }\end{array}$ \\
\hline ROA & 0.150977 & 0.025437 & 0.415302 & 1.249046 \\
& $(0.927290)$ & $(0.980)$ & $(0.662)$ & $(0.258)$ \\
\hline ROE & 5.457047 & 1.700161 & 1.006766 & 1.782327 \\
& $(0.065316)$ & $(0.197)$ & $(0.371)$ & $0.088)$ \\
\hline
\end{tabular}

Note: the probabilities are in brackets

Source: Compiled by Authors (2019)

\section{Results of Stability Test for ROA}

Figure 1

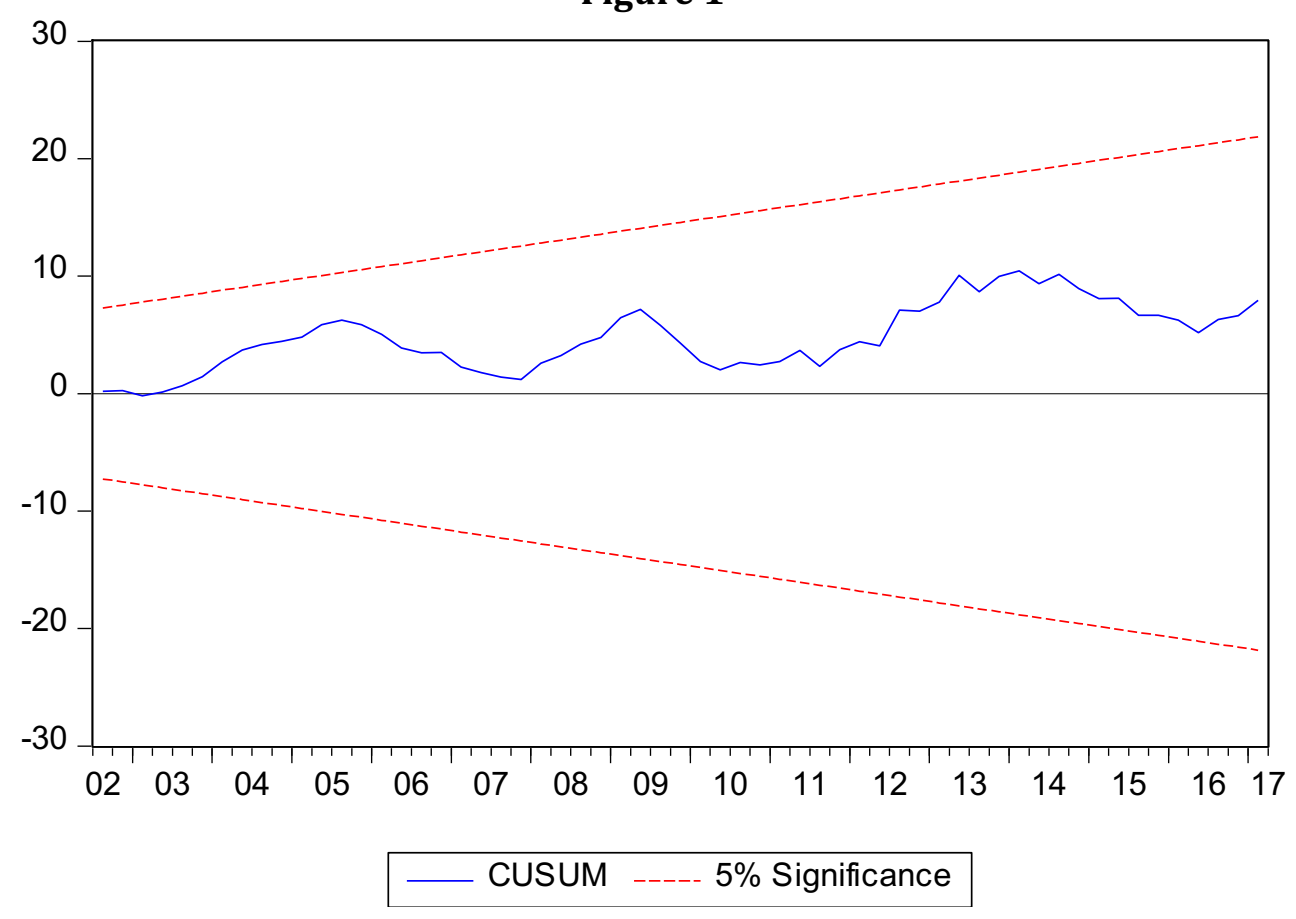


Figure 2

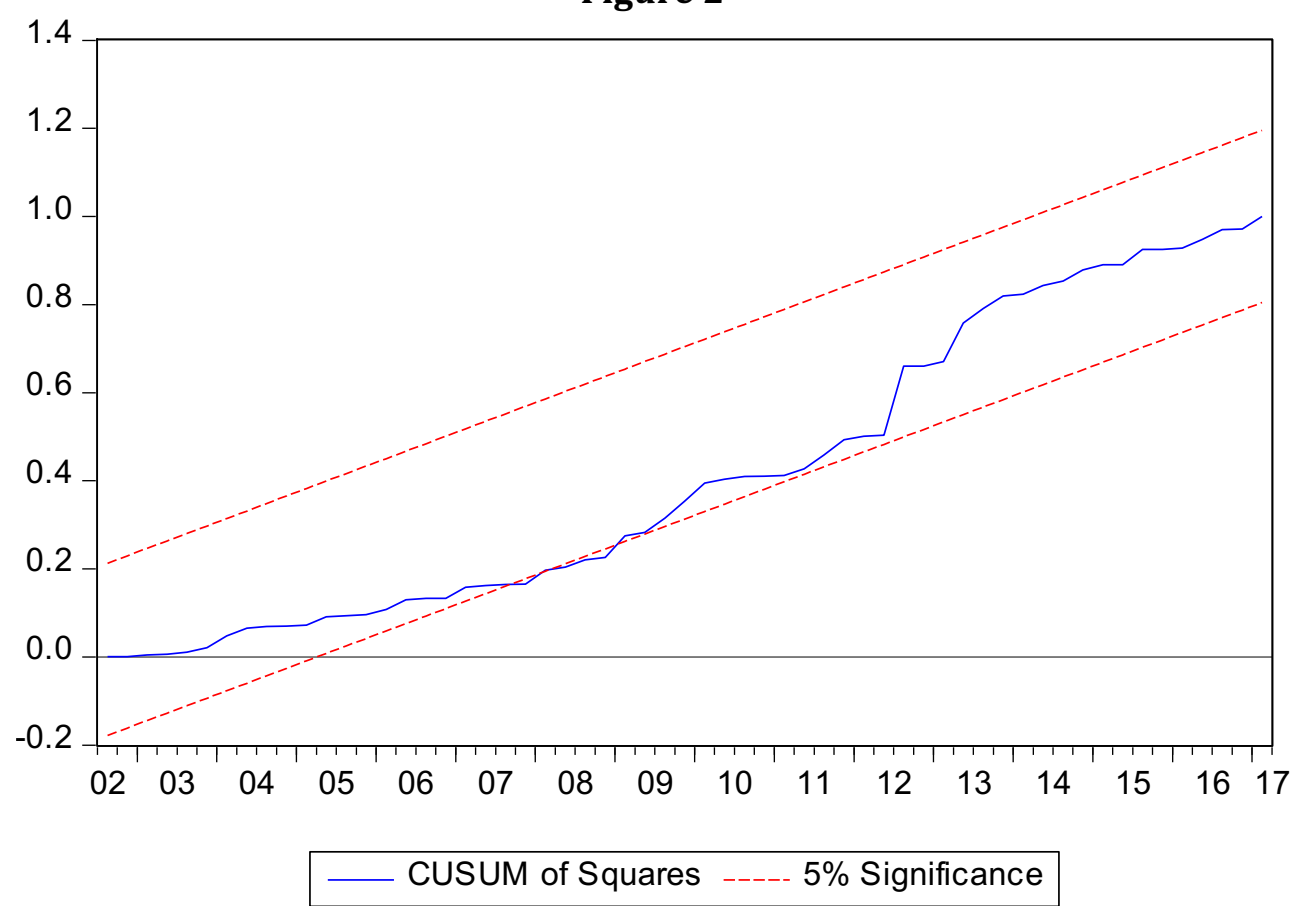

\section{Results of Stability Tests for ROE}

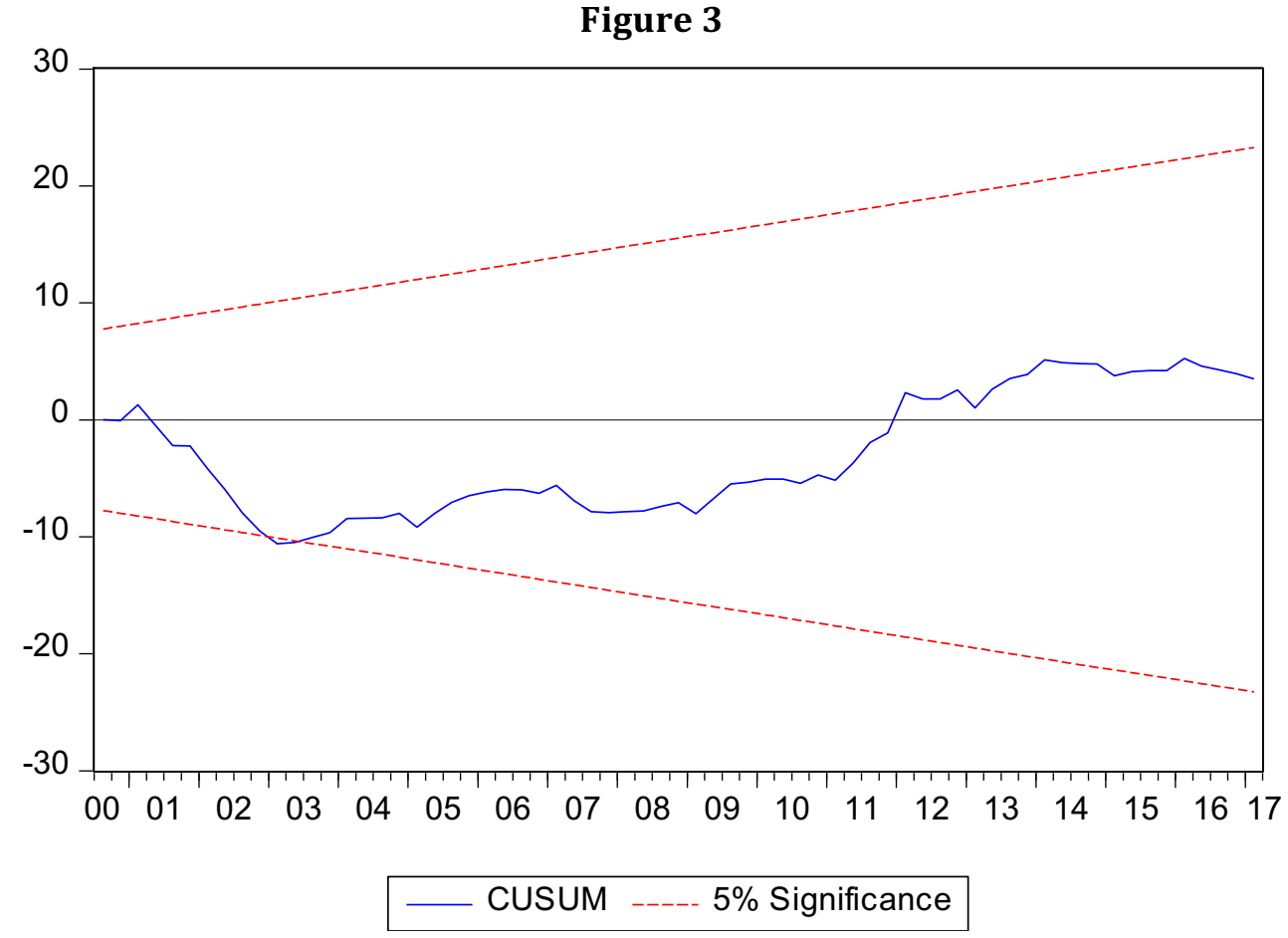




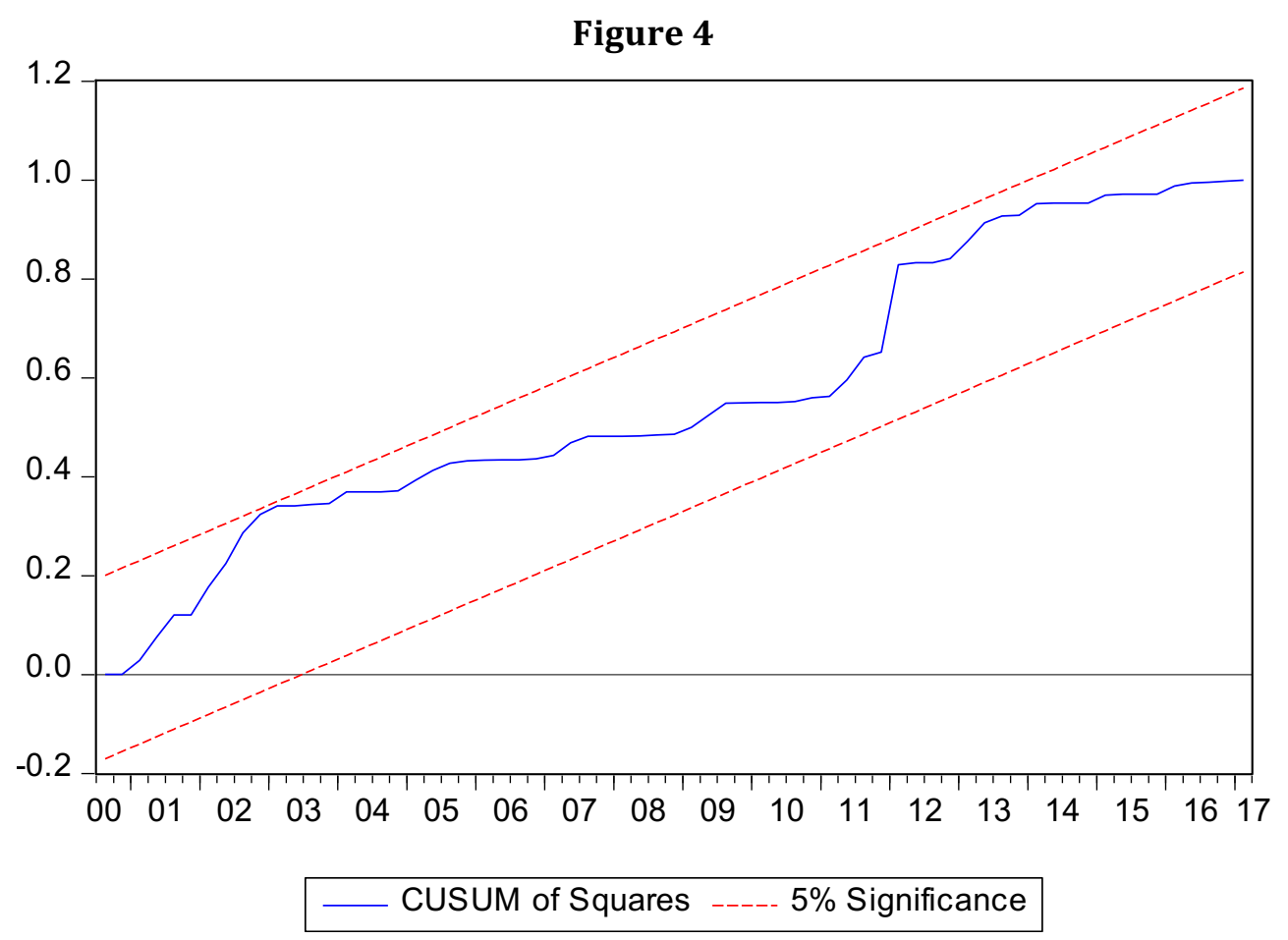

The two models passed all the residual diagnostics tests. This is evident from the probability of each test carried out. The non- significance of probabilities of F- statistic of Jaque-Bera Normality test, Breusch-Godfrey Serial Correlation LM test and Breusch-Pagan-Godfrey Heteroscedasticity test indicate that the ARDL models are free from autocorrelation and heteroscedasticity problems. The Ramsey Reset test also shows that the models are stable. The plots of the cumulative of the recursive residuals (CUSUM) and cumulative sum of squares of recursive residuals (CUSUMQ) in figures 1 to 4 lie within the boundaries confirming that the long run coefficients of ROA and ROE with respect to the financial deepening indicators in the ARDL models are stable.

\section{CONCLUSION AND RECOMMENDATION}

Ensuring that banks perform their intermediation function continuously made it important to investigate how deepening of the financial sector has affected the financial performance of Deposit Money Banks in Nigeria. To this end, two measures of financial performance; return on assets (ROA) and return on equity (ROE) with bank-based as well as market-based financial deepening measures were deployed for the purpose. The outcome of the study shows that while market capitalization has negative and significant influence of ROA, it has negative but insignificant influence on ROE. Private sector credit similarly exerts negative influence on the two profitability measures, although while it is insignificant in the case of ROA, it is significant for ROE. This inverse relationship could be due to the fact that the ratio of banks' nonperforming loan (NPLr) is quite high in Nigeria. The country has the second highest nonperforming loan ratio in Africa (Ndimele, 2018). Bank deposit liability however exerts positive and significant influence on both ROA and ROE.

From the fore going, this study concludes that financial deepening has influence on financial performance of Deposit Money Banks in Nigeria and recommends effective loan recovery strategy to mitigate the negative influence of private sector credit due to non-performing loan.

\section{References}

Akinkunmi, M. A. (2017). Determinants of banks' Profitability in Nigeria: Does Relative Market Power Matter? Journal of Finance and Bank Management, 5(1), 42-53. https://doi.org/10.15640/ifbm.v5n1a4 
Andele, S. O. (2013). Financial Deepening and Profitability of Commercial Banks in Kenya. A Research Proposal Submitted to the School of Business, University of Nairobi. Retrieved from erepository.uonbi.ac.ke/handle/11295/61612

Aspal, P. K., Dhawan, S. \& Nazneen, A. (2019). Significance of Bank Specific and Macroeconomic Determinants on Performance of Indian Private Sector Banks. International Journal of Economics and Financial Issues, 9(2), 168-174. https://doi.org/10.32479/ijefi.7727

Athansoglou, P. P.,Brissimis, S. N. \& Delis, M. D. (2008). Bank-Specific, Industry-Specific and Macroeconomic Determinants of Bank Profitability. Journal of International Financial Markets, Institutions and Money, 18(2), 121126. https://doi.org/10.1016/j.intfin.2006.07.001

Babazadeh, M. \& Farrokhnejad, F. (2012). Effects of Short Run and Long Run Changes in Foreign Exchange Rates on Banks' Profit. International Journal of Business and Management, 7(17), 70-77.

http://dx.doi:10.5539/ijbm.v7n17p70

Ghurtskaia, K. (2018). Macroeconomic Determinants of Bank Profitability: Evidence from Georgia. Ecoforum, 7(3), Retrieved from http://www.ecoforumjournal.ro/index.php/eco/article/view/831

Hasanov, F.J., Bayramli, N. \& Al-Musehel, N. (2018). Bank-Specific and Macroeconomic Determinants of Bank Profitability: Evidence from an Oil-Dependent Economy. International Journal of Financial Studies, 6(78), 1-21. Doi:10.3390/ijfs6030078

Kanwal \& Nadeem (2013). The Impact of Macroeconomic Variables on the Profitability of Listed Commercial Banks in Pakistan. European Journal of Business and Social Sciences, 2(9), 186-201. Retrieved from https://www.academia.edu/6213756

Kiganda, E. O. (2014). Effect of Macroeconomic Factors on Commercial Banks Profitability in Kenya: Case of Equity Bank Limited. Journal of Economics and Sustainable Development, 5(2), 46-56. Retrieved from https://www.researchgate.net/publication/316627452.

Kisaka, S. E., Ndii, G. M., Muriki, M. \& Muio, A. K. (2015). The Relationship between Mobile Banking Deepening and Financial Performance of Commercial Banks in Kenya. Research Journal of Finance and Accounting,6(10), 156-172. Retrieved from https://www.iiste.org/Journals/index.php/RJFA/article/download/22581/23394

Lee, J. Y., Glenn, G., Marinus, D. \& Inkyung, C. (2015). Measuring the Impact of the 2007-2009 Financial Crisis on the Performance and Profitability of U.S. Regional Banks. Advances in Management Accounting, 25, 181-206. Retrieved from https://www.researchgate.net/publication/282234152

Li, Y. (2009). Determinants of Banks Profitability and its Implication on Risk Management Practices: Panel Evidence from the UK in the Period 1999-2006. A Thesis Presented in Partial Fulfilment of Requirement for the Award of Degree of MA in Risk Management. University of Nottingham. Retrieved from eprints.nottingham.ac.uk/21374/2/07MAYuqiLi.pdf

Martinho, R., Oliviera, J. \& Oliviera, V. (2017). Bank Profitability and Macroeconomic Factors. Financial Stability Papers, 71, Banco De Portugal, 1-24. Retrieved from https://www.bportugal.pt/paper/

Nancy, J. C. (2017). The Effect of Financial Deepening on Financial Performance of Financial Institutions in Kenya. A Thesis Submitted in Partial Fulfilment of the Requirement for the Award of Master's Degree in Business Administration. University of Nairobi. Retrieved from erepository.uonbi.ac.ke/bitstream/handle/11295...

Ndimele, U. (2018). Nigeria Leads Africa in Non-Performing Loans. An Online Report. Retrieved from https://nairametrics.com

Nuhiu, A., Hoti, A. \& Bektashi, M. (2017). Determinants of Commercial Banks Profitability through Analysis of Financial Performance Indicators: Evidence from Kosovo. Verslas: Teorija Ir Praktika/Business: Theory and Practice, 18, 160-170. https://doi.org/10.3846/btp.2017.017

Nuriyeva, Z. (2014). Factors Affecting the Profitability of Azerbaijan Banking System. A Dissertation for the Award of Master's Degree, Eastern Mediterranean University, Turkey. Retrieved from http://irep.emu.edu.tr:8080/xmlui/bitstream/handle/11129/1616/NuriyevaZulfiyye.pdf?sequence=1

Olawumi, S. O., Lateef, L. A. \& Oladeji, E. O. (2017). Financial Deepening and Bank Performance: A case Study of Selected Commercial Banks in Nigeria. Journal of Mathematical Finance, 7, 519-539.

https://doi.org/10.4236/jmf.2017.73028 
Ongore \& Kusa (2013). Determinants of Financial Performance of Commercial Banks in Kenya. International Journal of Economics and Financial Issues, 3(1), 237-252. Retrieved from

https://www.researchgate.net/publication/306122535_

Otuori, O. H. (2013). Influence of Exchange Rate Determinants on the Performance of Banks in Kenya. European Journal of Management Sciences and Economics, 1(2), 86-98. Retrieved from https://www.coursehero.com/file/p5sa5j6/

Ozgor, 0.\& Gorus, M. S. (2016). Determinants of Deposit Bank Profitability: Evidence from Turkey. Journal of Applied Economics and Business Research, 6(13), 218-231. Retrieved from https://www.researchgate.net/publication/308676322.

Seferli, E. (2010). The Effect of macroeconomic Factors on the Performance of Azerbaijan Banking System. A Dissertation for the Award of Master's Degree, Dokuz Eylul University, Turkey. Retrieved fromhttp://acikerisim.deu.edu.tr/xmlui/bitstream/handle/12345/10837/261492.pdf?sequence=1\&isAllowed=y

Sheefeni, J. P. S. (2015). The Macroeconomic Determinants of Profitability among Commercial Banks in Namibia. Journal of Emerging Issues in Economics, Finance and Banking, 4(1), 1414-1431. Retrieved from https://www.researchgate.net/publication/308201789_

Sinha, P. \& Sharma, S. (2016). Determinants of Bank Profits and its Persistence in Indian Banks: A Study in a Dynamic Panel Data Framework. International Journal of System Assurance, Engineering and Management, $7,35-$ 46. https://doi.org/10.1007/s13198-015-0388-9

Tan, Y. (2016). The Impact of Risk and Competition on Bank Profitability in China. Journal of International Financial Markets, Institutions and Money, 40, 85-110. Retrieved from https://www.sciencedirect.com/science/article/pii/S1042443115001043

Zhang, C. \& Dong, L. (2011). Determinants of Bank Profitability: Evidence from the U.S Banking Sector. Research Thesis Submitted in Partial Fulfilment of the Requirement for the Award of Master's Degree in Financial Risk Management. Simon Fraser University. Retrieved from summit.sfu.ca/system/files/iritems1/13065/FRM 2011... • 